Budde and Miller (2015). Education Reform Journal, 2015, 1(1), 19-33

ERJournal

Education Reform Journal Volume 1 Number 12015

http: / /www.erjournal.org/

\title{
Examining Elementary Literacy Teachers' Perceptions of their Preparedness to Implement the English Language Arts Common Core State Standards
}

\author{
Melissa Adams-Budde* Samuel Miller**
}

\begin{abstract}
The purpose of our study was to examine elementary literacy teachers' perceptions of their preparedness to implement the ELA CCSS. We defined preparedness across three dimensions: teachers' perceived levels of knowledge of the standards and its components; efficacy to implement changes; and actual changes to their instructional practices. A survey was developed based on the literature and administered to 158 elementary school teachers in two districts. Findings document the nature of their professional development and identify areas where additional development opportunities are necessary. While all teachers reported receiving professional development on the ELA CCSS, they varied in knowledge ratings across various dimensions of the standards, self-efficacy ratings, and the degree they reported implementing changes in their practice with the introduction of the ELA CCSS. Discussion focuses on the need to provide more time and supports to teachers as they deal with the challenges of the new standards.
\end{abstract}

Keywords: English Language Arts Common Core State Standards, teacher preparedness, instructional change, professional development

\section{Introduction}

The Council of Chief State School Officers (CCSSO) and National Governors Association (NGA \& CCSSO, 2010) initiated a voluntary, state-led effort, to create a common set of internationally benchmarked standards in English/language arts and mathematics for K-12 students. Referred to as the Common Core State Standards (CCSS), they underscored the need for "fewer, clearer, and higher" standards to identify what high school graduates should know to be ready for the challenges of college and career (Rothman, 2012). While representing an important first step in school reform, critical questions remain about the degree to which teachers are prepared to implement the CCSS.

For several reasons, answers to questions of teachers' preparedness are not readily forthcoming because of how researchers' have conducted their studies. First, for most evaluations, state and district officials mainly serve as the respondents; (Anderson, Harrison, \& Lewis, 2012; Council of the Great City Schools, 2012; Kober, McIntosh, \& Rentner, 2013; Kober \& Rentner, 2011a; Kober \& Rentner, 2011b; Kober \& Rentner, 2012; McMurrer \& Frizzel, 2013; Murphy \& Regenstein, 2012; Rentner, 2013a; Rentner, 2013b; Rentner, 2013c); consequently, whether their evaluations of preparedness match teachers' can't be determined. Second, when teachers are the main respondents, researchers usually compared their general estimates of competence to teachers in other schools, districts, or states (ASCD, 2012) or simply provided broad estimates of preparedness based on single survey items (AFT, 2013; Editorial Projects in Education Research Center, 2013; Scholastic, \& Bill and Melinda Gates Foundation, 2013; Walker, 2013). It is not known whether teachers' perceptions of general preparedness might vary

* Corresponding Author, Ph.D. West Chester University of Pennsylvania, madams@ wcupa.edu

** Ph.D. University of North Carolina, Greensboro, sdmille2@uncg.edu 
according to particular dimensions of the CCSS (e.g., theoretical perspectives of literacy, use of informational texts, need for close reading, etc.); ability to teach certain students (e.g., lowachievers, ESL, \& special education); levels of preparation resulting from professional development activities; or certain entry level characteristics such as graduate degrees or years of experience (Clotfelter, Ladd, \& Vigdor, 2007; Goldhaber \& Anthony, 2007; Kane, Rockoff, \& Staiger, 2008). Finally, researchers have commented on the challenges of implementing the new standards without considering teachers' perspectives on this topic (Beach, 2011; Kober \& Renter, 2012; Sawchuk, 2012; Shanahan, 2013). Once again, whether teachers agree with these suggestions or would offer additional challenges can't be determined from the existing research. This study addresses these issues by asking teachers directly about their preparedness to implement the CCSS into practice, not just in general, but in terms of various dimension of the standards and student populations, as well as asking teachers directly about the challenges they face in the implementation of the CCSS standards.

This study adopts a social constructivist perspective, which highlights teachers' active engagement in constructing new knowledge and understanding through participation with others in activities and experiences (Vygotsky, 1978). As teachers engage in learning experiences and professional development around the standards, they actively and collectively make meaning of the standards. Beliefs about teaching and learning serve as a filter through which teachers process new knowledge and substantially influence their judgments and actions in the classroom (Levin \& He, 2008). In addition, teachers' beliefs influence choices relating to topics to teach and instructional strategies to adopt (Bandura, 2006; Chrysostomou \& Philippou, 2010; Pajares, 2006; Richardson, 1990).

To gain a more thorough understanding of teachers' perceptions of their preparedness to teach the CCSS, we sought a multi-dimensional view of readiness; a more complete understanding of how professional development activities might promote it; and a formal evaluation of whether professional development and other entry level characteristics predicted their preparation levels. Accordingly, we identified three levels of teachers' preparedness: (a) their understanding of the CCSS and its components, (b) their confidence to use this knowledge to align instructional practices with CCSS's expectations; and (3) actual changes in their instructional practices (Duffy, 2005; Schraw, 2006). Having knowledge of the CCSS and its subtopics serve as an important first step towards developing preparedness, requiring a reconciliation between past and newly acquired knowledge; confidence or efficacy serves as mediator between knowledge and teachers' actions to align instruction, likely influencing the degree to which teachers use knowledge to make instructional changes (Bandura, 1986; Emmer \& Hickman, 1991; Giallo \& Little, 2003; Ormrod, 2006); and existing changes in instructional practices serve as an indicator of teachers' ability to apply knowledge given their confidence and knowledge levels (Bandura, 1986; Berliner, 2004; Turner, 2006; Zimmerman, 1998).

While professional development likely influences teachers' preparedness, research shows how the quality, quantity, content of its activities; how it is formatted; and who presents the information influences its effectiveness (Birman, Desimone, Porter, \& Garet, 2000; Learning Forward, 2012; McLaughlin \& Overturf, 2012). Even with quality professional development, researchers still believe teachers need long-term and ongoing support because CCSS represent a major change in focus and emphasis from prior reform efforts (ASCD, 2012; Hall \& Hord, 2011; Murphy \& Regenstein, 2012; Wixson, 2013). To evaluate professional development, recommendations from two leading researchers, Guskey (2009) and Desimone (2009), were combined to produce the following criteria: time (duration); collaboration in problem solving (active learning and collective participation); school-based orientation; strong leadership; content 
Budde and Miller (2015). Education Reform Journal, 2015, 1(1), 19-33

focus; and coherence. Our next consideration was to examine years of teaching experience, additional degrees, coursework, or any qualifications that likely played a role in shaping teachers' perceptions of their preparedness (Clotfelter, Ladd, \& Vigdor, 2007; Goldhaber \& Anthony, 2007; Kane, Rockoff, \& Staiger, 2008; Smith \& Strahan, 2004).

This study offers both theoretical and practical implications for studying the adoption of new learning standards. In terms of theoretical implications, it supports the need for researchers to adopt a multi-dimensional perspective of teacher preparedness, in which preparedness is not viewed as single entity, but rather one that is multifaceted and varied. With regard to practical implications, it moves the discussion beyond simply asking teachers if they are ready to implement the new CCSS, to asking them about their readiness in terms of their knowledge of the standards, their self-efficacy to implement the standards into practice, and the degree of changes in practice they have made. In addition, it looks at the extent to which this readiness applies to specific dimensions of the CCSS and not others.

To limit the scope of the study, we focused on English Language Arts Standards at the elementary grade levels in two school districts. The following research questions guide this effort:

1. To what extent do teachers feel prepared to implement the ELA CCSS?

a. What level of understanding do teachers have regarding the ELA CCSS and its components (e.g., topics, general standards, \& assessment)?

b. How do teachers rate their efficacy to teach the ELA CCSS?

c. What changes do teachers report making to their instruction to meet the expectations of the new ELA CCSS?

2. What types of professional development have teachers received?

3. How do they rate the quality of their professional development opportunities?

4. To what extent are teachers' evaluations of their preparedness (i.e., knowledge of components, general efficacies, \& instructional changes) predicted by teacher (e.g., advanced degrees, years of experience) \& school characteristics (rural versus urban), and professional development?

\section{Methodology}

This study utilized a cross-sectional survey with data collected at one point in time from participants at 20 elementary schools in two school districts (Creswell, 2003). The survey was administered online to participants using Qualtrics software.

\section{Population and Sample}

Elementary English language arts teachers from two school systems in a southeastern state participated in the study. System A is a county system with 15 elementary schools, four middle schools, five high schools and one alternative school. Based on state-mandated 2012-2013 accountability assessments, eight of its elementary schools met expected growth, four exceeded expected growth, and three failed to meet expected growth. The county has 1,042 licensed, fulltime employees of whom 575 hold masters or advanced degrees, 11 hold doctoral degrees, and 149 achieved national board certification. The county serves more than 13,000 students. The ethnic composition of the student population is $63.2 \%$ white, $20.4 \%$ black, $10.7 \%$ Hispanic, $4.9 \%$ multi-racial, .4\% Asian, and .4\% American Indian. Fifty-nine percent of students received free or reduced lunch. The graduation rate in 2011-2012 was $76 \%$. 
Budde and Miller (2015). Education Reform Journal, 2015, 1(1), 19-33

System B is located in a small city, comprised of five elementary schools, two middle schools, one high school and one early childhood center. According to 2012-2013 assessments, two elementary schools met expected growth requirements, one exceeded expected growth, and two failed to meet expected growth. The city system has 438 certified staff members of 152 hold advanced degrees and 52 are national board certified. Approximately 4,700 students are enrolled in the school district of which $40.3 \%$ are white, $15.2 \%$ are black, $38.7 \%$ are Hispanic, $1.5 \%$ are Asian, 0.3\% are American Indian and 4.13\% are multi-racial. In the 2013-2014 school year, $73.65 \%$ of the students qualified for free or reduced lunch. The high school graduation rate for 2013 was $86.3 \%$.

All elementary English language arts teachers from both school systems were invited to participate in the study at the request of the school district. The response rate for teachers in School System A was 50\% $(\mathrm{n}=123)$ and the response rate for teachers in School System B was $29 \%(\mathrm{n}=35)$.

\section{Instrumentation}

Data was collected using an online survey which participants received a link to via email using the Qualtrics program. The two authors designed the survey using the Editorial Projects in Education (EPE) Research Center's survey as a foundation (Editorial Projects in Education Research Center, 2013). This survey was designed for teachers and provided the most comprehensive framework for evaluating teachers' perceptions of preparedness. Questions were modified or added to (a) collect more detailed information on teachers' professional development, such as the number of opportunities, hours, and quality ratings for professional development offered by a variety of entities; (b) to determine teachers' knowledge rating of specific components and topics related to the ELA CCSS; (c) to elicit more specific information on teachers' efficacy to implement instructional changes, and (d) to identify how teachers changed their instructional practices as a result of Common Core implementation. The final survey consisted of 37 survey items, 10 with multiple questions, across 5 categories: background information (e.g., How many years of teaching experience do you have?), professional development experiences (e.g., Which of the following topics have been addressed in your formal professional development? Check all that apply.), perceived knowledge of the standards and its components and topics (e.g., Please rate your overall level of understanding of the College and Career anchor standards.), self-efficacy to implement the standards (e.g., On a five-point scale, where 5 is "Very Prepared" and 1 is "Not at All Prepared," how prepared do you personal feel to teach the ELA CCSS to the following groups of students (all students, ELLs, students with disabilities, low income students, academically at-risk students)?), and reports of changes in instructional practice (e.g., Rate your level of agreement with the following statement, "My practices have changed with the ELA CCSS.). Thirty-five survey items had a closed response format and 2 were open-ended. Of the 35 closed response items, 20 were Likert scale items and the remaining 15 were multiple choice items that elicited information on participants' background or more detailed information, such as the format(s) and provider(s) of their professional development opportunities, topics addressed in professional development, materials and planning consideration as well as instructional teaching strategies from the previous week of teaching.

The construct validity of the content of the survey was determined by analyzing the different components of the ELA CCSS, a review of established survey instruments, and a review of the research literature (Litwin, 1995). The survey instrument was shared with experts in the 
Budde and Miller (2015). Education Reform Journal, 2015, 1(1), 19-33

field; in literacy, the ELA CCSS, and educational measurement; and revised based on feedback. These actions allowed us to determine its content and face validity. We looked at convergent validity and reliability by establishing constructs with a factor analysis and looked at correlations between constructs to note positive relationships. As a final step, we then piloted the survey and asked recipients to note any areas of misunderstanding; then we looked at variability of individual items to see if variances were equivalent among items and normally distributed. The internal reliability of the survey was determined using Cronbach's alpha rating for each of the summary scores dealing with teachers' attitudes and beliefs: knowledge, self-efficacy, instructional change, and professional development quality and were .81, .85, .82, and .71, respectively (Howell, 2007).

\section{Coding and Analysis}

Open-ended survey items were coded following Miles and Huberman's (1994) recommendations of data reduction, data display, and drawing and verifying conclusions. In phase one, participants' responses were open-coded and organized in a three-column chart with researcher notes. In phase two, codes were refined into common categories and a table was created with categories and corresponding responses. Frequency counts were used to determine the most commonly referenced responses. Finally, phase-three involved the creation of thematic codes by collapsing the categories from phase two into major themes (Merriam, 1985).

Analyses of the closed-ended items included two steps. The first included a descriptive analysis to see if each item demonstrated appropriate levels of distribution (skewness $\leq \pm 2.0$ ) for conducting parametric analyses. For multi-options multiple-choice items, percentages were calculated for the total number of respondents who selected each answer choice. The second analysis addressed the first three research questions, including related sub-questions. Repeated measures ANOVAs compared differences; when significance was found, Bonferroni's pairwise comparisons were utilized; whenever the assumption of sphericity was violated, Greenhouse Geisser corrections were used to adjust the degrees of freedom (Howell, 2007). For the final question, scores were calculated for teachers' knowledge, self-efficacy, and instructional change by adding teachers' responses to the items in each respective area. Similarly, summary scores were calculated for factors influencing teachers' preparedness: professional development opportunities, professional development hours, professional development quality, years of experience, educational qualifications and school group. Forward selection multiple regressions determined factors that predicted variances in teachers' knowledge, self-efficacy, and instructional change scores: this method was selected because of a lack of an existing theory regarding factors most likely to influence teachers' perceptions of preparedness (Field, 2013).

\section{Results}

Results were first separated by school district; however, when no significant differences were found (independent t-test, Howell, 2007), data were combined for subsequent analysis. Consistent with the order of research questions, findings will be shared below for teachers' perceptions of preparedness, in terms of their ratings of their levels of knowledge, self-efficacy, and reported changes; for teachers' professional development experiences; and for influences on teachers' perceptions of their preparedness. 
Budde and Miller (2015). Education Reform Journal, 2015, 1(1), 19-33

\section{Perceptions of Preparedness to Teach the ELA CCSS}

Knowledge. In evaluating perceptions of preparedness for implementing the ELA CCSS, teachers' knowledge of standards and its components were evaluated. Two sets of questions with eleven items asked teachers' to rate knowledge of the standards, its components and topics, and corresponding assessments on a scale with 4 representing very knowledgeable and 1 representing not at all knowledgeable. In descending order, means and standard deviations for 158 respondents were (a) different types of informational texts $(3.24, .59)$, (b) content area literacy instruction $(3.05, .57)$, (c) instructional strategies for teaching complex texts $(2.85, .70)$, (d) foundational skills $(2.90, .64$, (e) close reading of text $(2.82, .66)$, (f) ELA CCSS $(2.80, .91)$, (g) CCR Anchor Standards $(2.23, .85)$, (h) new state assessments $(2.08, .72)$, (i) technology enhanced state assessments $(1.92, .69)$, (j) performance tasks on state assessments $(1.92, .74)$. and (k) constructed responses on state assessments $(1.90, .74)$.

A repeated measures ANOVA $\left(F(6.245,980.428)=101.878 p<.001, \eta_{\mathrm{p}}{ }^{2}=.394\right)$ yielded significant differences and post hoc tests $(p<.05)$ revealed ratings for understanding of the ELA CCSS and its topics (e.g., close reading, types of informational text, complex text, content area literacy instruction, and foundational skills) as significantly higher than knowledge of the new state assessments and corresponding new question formats, as well as knowledge of the CCR Anchor Standards. Teachers' knowledge of standards and its components were rated higher than knowledge of the aligned assessments and their question formats. The one exception is that teachers rated knowledge of the CCR Anchor Standards lower than their other knowledge of the standards.

Self-efficacy. In evaluating self-efficacy, five items were used. Two asked teachers to rate level of preparedness for teaching different populations of students and compare it with that of their colleagues, school, district, and state. Two asked if teachers had the necessary materials, resources, and supports to be self-efficacious. One open-ended item asked teachers to list the challenges they faced implementing the standards into practice.

In descending order, means and standard deviations for 158 respondents with the teaching of different populations on a five-point scale were (a) teaching students in general (3.92, .74), (b) low income students $(3.60, .90)$, (c) academically at-risk students (3.43, .91), (d) English language learners $(3.19, .93)$, and (e) students with disabilities $(3.17, .90)$. A repeated measures ANOVA, $\left.F(3.217,498.690)=52.477, p<.001, \eta_{\mathrm{p}}{ }^{2}=.253\right)$ and post hoc tests $(p<.05)$ showed ratings for teaching students in general were higher significantly than ratings for teaching English language learners, students with disabilities, low income students, and academically at-risk students. Also, teachers' perceptions of preparedness to teach students with disabilities had the lowest rating and differed significantly from their efficacy to teach all groups, except English language learners. When asked to compare preparedness to other groups (peers, school, district and state), teachers' means ranged between 3.31 and 3.73 on a five-point scale. A repeated measures ANOVA, $\left.F(2.781,433.791)=25.138, p<.001, \eta_{\mathrm{p}}{ }^{2}=.139\right)$ followed by pairwise comparisons showed how teachers' ratings of confidence in their state was significantly lower than their confidence in themselves, colleagues, school, and district.

Two sets of items examined what teachers needed to improve their efficacy. Teachers' need for textbooks and other curricula materials was rated higher than a need for additional informational text. A repeated measures ANOVA $F(1.00,155)=76.883 p<.000, \eta_{\mathrm{p}}{ }^{2}=.332$ ) confirmed this difference. Teachers then identified additional factors that could help them to become more confident. Teachers selected multiple responses from a list of eight options or 
wrote in their own response. More than $80 \%$ of teachers selected between three and seven factors with the emphasis on the more practical applications of knowledge: a criterion of $50 \%$ was used to designate frequently cited needs. They included a need for more planning time, collaboration with colleagues, access to curriculum resources aligned to the standards and assessments, and more professional development; less frequently selected needs included more information about how the standards will change instructional practices, how the standards will change what is expected of students, and how the ELA CCSS differed from state's standards prior to the CCSS.

In addition to self-efficacy ratings and items relating to needs for improving self-efficacy, teachers listed what they considered to be challenges to teaching the ELA CCSS. One hundred twenty-three teachers $(84 \%)$ responded to this open-ended item providing an initial list of 20 challenges: they were collapsed into six thematic codes. The most commonly cited challenge was a lack of resources and materials aligned with the standards, followed by the need for additional time. Teachers cited the need for more time to plan, to collaborate with colleagues, to understand the standards fully and adapt their instruction, and to teach students everything that was expected. Teachers described challenges related to assessments as figuring out how to assess the standards, the increased rigor of the assessments, the frequency with which they were expected to assess student learning, and communicating with parents.

Instructional change. Eight sets of questions examined teachers' reports of instructional changes. Eighty-nine percent of teachers agreed or strongly agreed that the ELA CCSS required major changes and $90 \%$ agreed or strongly agreed that their instructional practices had changed (mean scores for these items were 3.12 and 3.10 respectively on a 4.0 scale). As a follow-up, teachers rated the degree to which they already implemented the standards into their practices: $37 \%$ reported that they were incorporated into some areas of their teaching, while $63 \%$ reported that they were fully incorporated into their practice. The next set looked closely at the extent to which teachers reported implementing changes. The greatest changes were in reading (71\%), followed by writing (64\%), science $(51 \%)$ and social studies $(46 \%)$. A repeated measures ANOVA determined the mean values for change in practices differed significantly, $(F(2.049$, $\left.315.949)=35.014, p<.001, \eta_{\mathrm{p}}{ }^{2}=.183\right)$ : post hoc tests revealed no difference for changes in reading and writing practices; however, changes in reading and writing were higher than changes in science and social studies practices, which did not differ significantly.

The third set of questions examined teachers' previous week's literacy instruction by looking at their planning and instructional activities. These questions were included to implicitly ask teachers about instructional changes. The first item asked teachers to report the materials used during planning; teachers could add responses. During planning, using a criterion of fifty percent, teachers mainly relied on district's pacing guides, the ELA CCSS, and self-created or borrowed materials. Less frequently materials were from a core (basal) program or supplementary program, from professional sources such as books and journals, and results from student assessment data. More than $80 \%$ of teachers reported using three to eight resources when planning instruction. Additionally, when asked to identify their thinking during planning, every option received more than a 50\% rating with the highest on developing critical thinking questions, identifying strategies for differentiation, considering unfamiliar vocabulary, and engaging students in discussions.

An additional item asked teachers about the frequency with which they employed particular instructional strategies or practices in their previous week's instruction. Strategies were placed into one of three categories: the most frequent strategies were used by at least $80 \%$ of teachers, middle category strategies included those used by $50 \%$ and $80 \%$ of teachers, less frequently used strategies were used by fewer than $50 \%$ of teachers. Most frequently 
Budde and Miller (2015). Education Reform Journal, 2015, 1(1), 19-33

implemented strategies included discussing ideas presented in a text, reading informational text, reading a text multiple times, providing text evidence to support ideas, setting a purpose from reading, reading challenging text, and evaluating ideas presented in a text. Middle category strategies included analyzing text features, applying learning to the real world, evaluating author's purpose, comparing content across texts, providing evidence to support ideas when writing, analyzing text structure, and highlighting or annotating text. Less frequently used strategies were taking notes on a text read, writing narrative text, writing informational text, analyzing different authors' perspectives on the same content, researching a topic, and writing argumentative text. The same pattern was discovered when teachers were asked on an openended question to describe how their instruction had changed as a result of the new standards.

\section{Professional Development}

The next set of analyses focused on teachers' professional development. Teachers entered the number of opportunities and hours of professional development provided by their school and district, state, professional organizations, colleges or universities, or other entities and rated the quality of each. Additional items asked about presentation format, provider, and topics addressed. Teachers reported the amount of time they spent outside of formal professional development learning about the standards from a variety of sources (e.g., district and state websites, professional organization, general news and media). The final item asked teachers to rate the quality of professional development experiences relative to standards for effective professional development.

The greatest number of opportunities occurred at the school $(56 \%)$ and district $(30 \%)$ levels, followed by professional organizations (7\%), the state (4\%), and a college or university (3\%). Accordingly, school and district professional development required a high percentage of teachers' time $(78 \%)$, followed by professional organizations $(8.5 \%)$, colleges or universities $(8.5 \%)$, and the state (5\%). Similarly, the majority of teachers attended professional development at the school and district level ( $88 \%$ and $84 \%$, respectively), followed by professional organizations $(22 \%)$, the state $(16 \%)$ and colleges and universities (13\%). Per these findings, teachers had about five opportunities at the school with each session averaging about two hours and two to three opportunities at the district level with each session lasting about five hours. In most opportunities, presenters used structured settings such as seminars, lectures, or conferences (31\%), collaborative planning time with colleagues (29\%), and professional learning communities (18\%). Job-embedded training or coaching (10\%) and online webinars or videos (10\%) were less commonly employed. The majority of teachers, an estimated 8 of 10 , experienced two, three, or four formats across professional development opportunities, with the three previously stated formats being the most common with more than $80 \%$ of opportunities presented by a staff member from their school, another school, or the district office.

When reviewing topics covered during professional development, a criterion of $50 \%$ was used to designate a frequently addressed topic. Of the 15 topics listed, six met this criterion. The top three included the CCSS in English Language Arts, the CCSS in Mathematics, and the alignment between the CCSS and the state's previous standards, followed by the teaching higher order and critical thinking, integrating literacy into the content areas, and collaborating with colleagues to teach the standards. Less commonly addressed topics included curricular materials and resources to teach the standards, teaching informational text, adapting classroom assessments, key shifts from previous standards, research on best practices, teaching close and critical reading, teaching to specific groups of students (e.g., students with disabilities and 
Budde and Miller (2015). Education Reform Journal, 2015, 1(1), 19-33

English language learners), determining text complexity and/or teaching complex texts, and new state assessments developed by the multi-state consortia. With the exceptions of literacy in the content areas and higher order thinking skills, all of the commonly addressed topics dealt with the standards from a general perspective.

Because professional learning occurs outside the context of formal professional development experiences, teachers also estimated amount of time they spent learning about the ELA CCSS from a variety of informational sources. Greater than $90 \%$ of teachers turned to outside sources to learn more about the ELA CCSS with district and state websites being the most frequented portals.

Teachers rated the quality of professional development experiences on a 5-point scale. Teachers rated the quality of professional development experiences provided by their school $(M=$ $3.34)$, district $(M=3.43)$, and state $(M=3.54)$ lower than those offered by colleges and universities $(M=4.03)$ and professional organizations $(M=4.21)$. Because the number of teachers who participated in the professional development provided by different entities was unequal, the only statistical comparison was between ratings for the state and district (Howell, 2007). A repeated measures $\operatorname{ANOVA}\left(F(1,128)=1.506, p=.222, \eta_{\mathrm{p}}{ }^{2}=.012\right)$ revealed no difference in teachers' ratings for the school and district.

The next analysis examined ratings of the extent to which the professional development adhered to recommended professional development standards. Mean ratings ranged from a high of 3.21 to a low of 2.68 on a 4.0 scale. Teachers' ratings were found to be significantly different using a repeated measures $\operatorname{ANOVA}\left(F(4.650,725.356)=49.312, p<.001, \eta_{\mathrm{p}}{ }^{2}=.240\right)$ with posthoc comparisons $(p<.05)$ revealing a higher overall rating for two items; teachers rated the presence of collaborative environments and support from school leadership for professional learning as the most frequently implemented standards.

\section{Influences on Teachers' Perceptions of Their Preparedness to Teach the ELA CCSS}

The final analyses looked at the extent to which perceptions of preparedness (i.e., knowledge, self-efficacy, and instructional change) was predicted by teacher (e.g., advanced degrees, years of experience) and school characteristics (e.g., rural versus urban) and professional development experiences.

The first analysis examined predictors for knowledge of the ELA CCSS. Four significant correlations existed between the knowledge and professional development quality ratings $(p<$ $.001)$, educational qualifications $(p=.001)$, professional development hours $(p=.002)$, and professional development opportunities $(p=.020)$. A forward selection multiple regression revealed significant differences in knowledge $(F(1,155)=8.621, p=.004 ; \mathrm{r}=.367)$ to be predicted by their perceptions of the quality of professional development opportunities $\left(R^{2}=\right.$ .087: Adjusted $\left.R^{2}=.081\right)$ and educational qualifications $\left(R^{2}=.135\right.$; Adjusted $\left.R^{2}=.124\right)$. The second examined predictors for self-efficacy. Two significant correlations existed between selfefficacy and professional development quality ratings $(p<.000)$ and professional development hours $(p=.002)$. A forward selection multiple regression revealed significant differences in efficacy $(F(1,156)=29.381, p<.000 ; \mathrm{r}=.398)$ to be based on teachers' perceptions of the quality of their professional development opportunities $\left(R^{2}=.158\right.$ : Adjusted $\left.R^{2}=.153\right)$. The third analysis examined predictors for instructional changes. Five significant correlations exist between instructional changes and professional development quality ratings $(p<.000)$, professional development hours $(p<.000)$, professional development opportunities $(p=.014)$, 
years of teaching experience $(\mathrm{p}=.011)$, and educational qualifications $(p=.033)$. A forward selection multiple regression revealed significant differences in instructional change $(F(1,153)=$ $6.030, \mathrm{p}=.015 ; \mathrm{r}=.455)$ based on the time spent in professional development, teachers' perceptions of the quality of their professional development opportunities, years of experience, and educational qualifications $\left(R^{2}=.207\right.$ : Adjusted $\left.R^{2}=.187\right)$.

\section{Discussion}

The use of a multidimensional view of teachers' preparedness to teach ELA CCSS revealed important differences in their knowledge of the standards and its components, confidence to use this knowledge to teach different student populations, and actual changes in classroom instruction. Teachers rated their general knowledge of the standards and of informational texts, content area literacy instruction, instructional strategies for teaching complex texts, foundational skills, close reading of text higher than their knowledge of the assessments and CCR Anchor Standards. Educational qualifications and perceptions of the quality of professional development activities were the best predictors for knowledge. Next, efficacy for preparing students in general was higher than their efficacy for teaching specific groups of students, such as students with disabilities, low-income students, academically at-risk students, and English language learners. Perceptions of the quality of the professional development activities were the sole predictor for teachers' efficacy. When asked about preparedness in terms of actual changes in instructional practice, practically every teacher believed the standards required fundamental changes in practice and reported making adjustments to instruction; however, these changes were most obvious in reading, with fewer modifications occurring in writing, science, and social studies. Perceptions of the quality of professional development activities and teachers' years of experience and educational qualifications best predicted variance on this measure.

Teachers' preparedness across the three dimensions---knowledge, efficacy, and actual instructional changes-- aligned closely with districts' efforts to provide support. Districts' professional development mainly addressed standards from a general perspective, with most of the emphasis on the language arts and mathematics standards and the alignment between them and the state's previous standards. While districts emphasized topics such as informational text, content area literacy, foundational skills and close reading, there was little, if any, emphasis on how teachers might use this knowledge outside of reading or how teachers might use it to teach specific populations of students. As a result, even though teachers spent several thousand hours in professional development during the first two years of the standards' implementation, they overwhelmingly requested more time to understand and plan with the standards and assessments and to adjust instruction to meet the needs of underserved student populations. They also wanted to have curricular materials, assessments, and resources that were aligned to the standards and wanted time to plan with colleagues on the use of these resources. Teachers recognized areas where they needed to improve their preparation and pointed to professional development as a means for strengthening their preparedness.

While teachers' responses across the three levels of preparedness varied, almost everyone reported taking steps to increase his or her knowledge and self-efficacy relating to the standards and making corresponding changes to his or her instructional practices. None of their responses contained negative statements regarding the standards or their efforts to adjust; if anything, teachers, and perhaps district and state level administrators, simply underestimated how long it would take to fully meet the challenges of the new standards and assessments. An important first 
step might be to provide teachers with additional time to continue to increase their knowledge of the standards, to plan instruction around them, and to adjust their instructional practices. Related to this opportunity, teachers need to acquire further knowledge of the assessments and the CCR Anchor Standards because expertise in these areas would help them to differentiate instruction to meet the needs of all students (Applebee, 2013, Valencia \& Wixson, 2013).

Given the difficulties of applying knowledge, teachers asked for more opportunities to translate their knowledge to actual classroom practices. At this point, only a minority of teachers, those with greater experience and advanced degrees, implemented substantive changes outside of reading. When addressing this challenge, administrators and curriculum directors might use findings from the prediction analyses to evaluate the effectiveness of any support activity. Across these analyses, teachers, who evaluated highly the quality of professional development, reported higher levels of preparedness. Thus, individuals, who direct the professional development, might survey or interview teachers to evaluate perceptions of the value of any activity and make any necessary modifications.

The CCSS represent perhaps the most challenging reform in the history of the standards movement, in that, educators and politicians are attempting to promote a globally competitive school system based on the joint outcomes of equity and excellence (Darling-Hammond, 2010; Sleeter, 2007; Sleeter \& Stillman, 2007). Future research could assist this endeavor by studying further what teachers need to fully implement the standards to meet this new expectation. In these two districts, adoption of the standards and attempts to facilitate their implementation happened quickly and, at this point, neither teachers, nor administrators appear to be prepared adequately to meet this new challenge. Studies might explore how teachers' implementation of the standards interacts with accountability pressures to demonstrate high-test scores ( $\mathrm{Au}, 2007$ ). Further studies also might look at the complex nature of preparedness and how levels of understanding evolve over time with efficacy and actual instructional changes. Regardless, with any effort to further understand this reform, we believe teachers should be a central focus. Throughout this study, teachers provided positive detailed recommendations as to what they needed as they dealt with the daily challenges of gaining an adequate understanding of expectations and implementing the necessary instructional changes. While the expectations of the ELA CCSS were yet to be fully realized, teachers believed they were moving in the right direction.

There are several limitations to this study. First, all data were collected through survey methods, which limits the depth of understanding teachers' perceptions of their preparedness one can glean from the data. There is no observational data to triangulate what teachers report as their changes in practice (Lincoln \& Guba, 1985). Second, the results are only from two school districts and are not generalizable to all elementary teachers' perceptions of their preparedness for implementation. Third, this survey only looked at elementary teachers' perceptions of their preparedness, not middle and high school teachers and it only looked at the ELA CCSS, not mathematics.

\section{Conclusion}

All teachers reported participating in professional development related to the ELA CCSS, with most teachers' professional development occurring at the local level, either provided by their school or district. These opportunities were largely in the format of formal, structured meeting or collaborative planning with colleagues and were most often led by staff members from the teachers' school, another school within the district, or from the central office. The most commonly addressed topics dealt with the standards primarily from a general perspective, and 
rarely addressed issues such as assessments, newly emphasized skills and topics (e.g., close/critical reading, text complexity), and teaching to different groups of students (e.g., students with disabilities, English language learners). Many participants also reported seeking additional informational on the standards from outside sources. In general, participants had positive perceptions of the quality of their professional development, with average quality ratings lower for professional development offered by the school, district, or state compared to that of professional development offered by a professional organization or college or university. Since teachers' rating of the quality of their professional development experiences was found to be the only consistent predictor across the three dimensions of preparedness, this appears to be a critical component for developing teachers' preparedness.

Despite the widespread participation in professional development, based on the results of this study, it appears that teachers do not believe that they are fully prepared to implement the ELA CCSS, yet they are making progress towards this goal. Teachers reported greater levels of knowledge and self-efficacy for implementation than changes in practices. However, teachers did report making changes in practice, mainly with their reading instruction, and acknowledged the need for continued change. Teachers simply asked for the necessary time, resources, and additional professional development to fully meet the demands of the more rigorous learning standards. 
Budde and Miller (2015). Education Reform Journal, 2015, 1(1), 19-33

\section{References}

American Federation of Teachers. (2013). AFT poll of 800 teachers finds strong support for Common Core Standards and a moratorium on stakes for new assessments until everything is aligned [Press Release]. Retrieved from http://www.aft.org/newspubs/ press/2013/050313.cfm.

Anderson, K., Harrison, T., \& Lewis, K. (2012). Plans to adopt and implement Common Core State Standards in the southeast region states (Issues \& Answers Report, REL 2012-No. 136). Washington, DC: U.S. Department of Education, Institute of Education Sciences, National Center for Education Evaluation and Regional Assistance, Regional Educational Laboratory Southeast. Retrieved from http://ies.ed.gov/ncee/edlabs

Applebee, A. N. (2013). Common Core State Standards: The promise and the peril in a national palimpsest. English Journal, 103(1), 25-33.

Association for Supervision and Curriculum Development (ASCD). (2012). Fulfilling the promise of the common core state standards. Retrieved from ASCD website: http://www.ascd.org/ASCD/pdf/siteASCD/commoncore/CCSSSummitReport.

$\mathrm{Au}$, W. (2007). High-stakes testing and curricular control: A qualitative metasynthesis. Educational Researcher, 36(5), 258-267.

Bandura, A. (1986). Social foundations of thought and action: A social cognitive theory. Englewood Cliffs, NJ: Prentice-Hall.

Bandura, A. (2006). Adolescent development from an agentic perspective. In F. Pajares \& T. Urdan (Eds.), Self-efficacy beliefs of adolescents (pp. 1-44). Greenwich, CT: Information Age Publishing.

Beach, R. (2011, December). Analyzing how formalists, cognitive-processing, and literacy practices learning paradigms shaping the implementation of the Common Core State Standards. Paper session presented at the Literacy Research Association, Jacksonville, FL.

Berliner, D. C. (2004). Describing the behavior and documenting the accomplishments of expert teachers. Bulletin of Science, Technology \& Society, 24(3), 200-212.

Birman, B. F., Desimone, L., Porter, A. C., \& Garet, M. S. (2000). Designing professional development that works. Educational Leadership, 57(8), 28-33.

Chrysostomou, M., \& Philippou, G. N. (2010). Teachers' epistemological beliefs and efficacy beliefs about mathematics. Procedia - Social and Behavior Sciences, 9, 1509-1515. doi: 10.10/j.sbspro.210.12.357

Clotfelter, C. T., Ladd, H. F., \& Vigdor, J. L. (2007). Teacher credentials and student achievement: Longitudinal analysis with fixed student effects. Economics of Educational Review, 26(2), 673-682.

Council of the Great City Schools. (2012). Implementing the Common Core State Standards in urban public schools - 2012. Retrieved from http://www. cgcs.org/cms/lib/DC00001581/ Centricity/Domain/87/Implementing\%20the\%20Common\%20Core\%20State\%20Standards.pdf

Creswell, J. W. (2003). Research design: Qualitative, quantitative, and mixed methods approaches. Thousand Oaks, CA: Sage.

Darling Hammond. (2010). The flat world of education: How America's commitment to equity will determine our future. New York: Teacher's College.

Desimone, L. M. (2009). Improving impact studies of teachers' professional development: Toward better conceptualizations and measures. Educational Researcher, 38(3), 181-199.

Duffy, G. G. (2005). Developing metacognitive teachers: Visioning and expert's changing role in teacher education and professional development. In S.E. Israel, C. C. Block, \& K. L. Bauserman (Eds.), Metacognition in literacy learning: Theory, assessment, instruction, and professional development (pp. 299-314). Mahwah, NJ: Routledge.

Editorial Projects in Education Research Center. (2013). Findings from a national survey of teacher perspectives on the Common Core. Bethesda, MD: Author.

Emmer, E., \& Hickman, J. (1991). Teacher efficacy in classroom management and discipline. Educational and Psychological Measurement, 51, 755-765.

Field, A. P. (2013). Discovering statistics using IBM SPSS Statistics: And sex and drugs and rock and roll $\left(4^{\text {th }}\right.$ ed.). London: Sage.

Giallo, R., \& Little, E. (2003). Classroom behaviour problems: The relationship between preparedness, classroom experiences, and self-efficacy in graduate and student teachers. Australian Journal of Education and Developmental Psychology, 3, 21-34. 
Budde and Miller (2015). Education Reform Journal, 2015, 1(1), 19-33

Goldhaber, D., \& Anthony, E. (2007). Can teacher quality be effectively assessed? National Board Certification as a signal of effective teaching. The Review of Economics and Statistics, 89, 134-150.

Guskey, T. R. (2009). Closing the knowledge gap on effective professional development. Education Horizons, 87(4), 224-233.

Hall, G. E., \& Hord, S. M. (2011). Implementation: Learning builds the bridge between research and practice. Journal of Staff Development, 32(4), 52-57.

Howell, D.C. (2007). Statistical methods for psychology: Sixth edition. Belmont, CA: Thomason Higher Education.

Kane, T. J., Rockoff, J. E., \& Staiger, D. O. (2008). What does certification tell us about teacher effectiveness? Evidence from New York City. Economics of Education Review, 27(6), 615-631.

Kober, N., McIntosh, S., \& Rentner, D. S. (2013). Year three of implementing the Common Core State Standards: Professional development for teachers and principals. Washington DC: Center for Educational Policy. Retrieved from Center for Educational Policy website: http://www.cepdc.org/display Document.cfm?DocumentID $=422$

Kober, N., \& Rentner, D. S. (2011a). States' progress and challenges in implementing Common Core State Standards. Washington DC: Center for Educational Policy. Retrieved from Center for Educational Policy website http://www.cep-dc.org/displayDocument.cfm? DocumentID=343

Kober, N., \& Rentner, D. S. (2011b). Progress and challenges in school districts' implementation. Washington DC: Center for Educational Policy. Retrieved from Center for Educational Policy website http://www.cep-dc.org/displayDocument. cfm?DocumentID=374

Kober, N., \& Rentner, D. S. (2012). Year two of implementing the Common Core State Standards: States' progress and challenges. Washington DC: Center for Educational Policy. Retrieved from Center for Educational Policy website: http://www.eric.ed.gov/ contentdelivery/ servlet/ERICServlet?accno=ED528907

Learning Forward. (2012). Definition of professional development. Oxford, OH: Learning Forward. Retrieved from: http://www.learningforward.org/who-we-are/professional-learning-definition\#.Uqt5A8RDtXk.

Levin, B., \& He, Y. (2008). Investigating the content and sources of teacher candidates' personal practical theories (PPTs). Journal of Teacher Education, 59(1), 55-68.doi: 10.1177/0022487107310749

Litwin, M. S. (1995). How to measure survey reliability and validity. The Survey Kit (Volume 7). Thousand Oaks, CA: Sage Publications.

Lincoln, Y. S., \& Guba, E. G. (1985). Naturalistic inquiry. Beverly Hills, CA: Sage.

McLaughlin, M., \& Overturf, B. J. (2012). The Common Core: Insights into the K-5 standards. Reading Teacher, 66(2), 153-164.

McMurrer, J., \& Frizzell, M. (2013). Year three of implementing the Common Core State Standards: State education agencies' views of postsecondary involvement. Washington DC: Center for Educational Policy. Retrieved from Center for Educational Policy website http://www.cep-dc.org/publications /index.cfm?selectedYear=2013

Merriam, S. B. (1985). The case study in educational research: A review of selected literature. Journal of Educational Thought, 19(3), 204-217.

Miles, M. B., Huberman, A. M. (1994). Qualitative data analysis, $\left(2^{\text {nd }}\right.$ ed.). Thousand Oaks, CA: Sage.

Murphy, P., \& Regenstein, E. (2012). Putting a price tag on the Common Core: How much will smart implementation cost. Thomas B. Fordham Institute. Washington, D.C.

National Governors Association (NGA) \& Council of Chief State School Officers (CCSSO). (2010). Common Core State Standards for English Language Arts \& Literacy in History/Social Studies, Science, and Technical Subjects. Washington, DC: CCSSO \& National Governors Association.

Ormrod, J. E. (2006). Educational psychology: Developing learners (5th ed.). Upper Saddle River, NJ: Pearson/Merrill Prentice Hall.

Pajares, M. F. (2006). Self-efficacy during childhood and adolescence: Implications for teachers and parents. In M. F. Pajares \& T. Urdan (Eds.), Self-efficacy beliefs of adolescents (pp. 339-367). Greenwich, CT: Information Age Publishing.

Rentner, D. S. (2013a). Year three of implementing the Common Core State Standards: An overview of states' progress and challenges. Washington DC: Center for Educational Policy. Retrieved from Center for Educational Policy website: http://www.cep-dc.org/publications/index.cfm? selectedYear=2013 
Budde and Miller (2015). Education Reform Journal, 2015, 1(1), 19-33

Rentner, D. S. (2013b). Year three of implementing the Common Core State Standards: State education agencies view on the federal role. Washington, DC: Center for Educational Policy. Retrieved from Center for Educational Policy website: http://www.cep-dc.org/publications/index.cfm? selectedYear $=2013$

Rentner, D. S. (2013c). Year three of implementing the Common Core State Standards: States prepare for Common Core assessments. Washington DC: Center for Educational Policy. Retrieved from Center for Educational Policy website http://www.cep-dc.org/ publications/index.cfm? selectedYear=2013

Richardson, V. (1990). Significant and worthwhile change in teaching practice. Educational Researcher, 19, $10-18$.

Rothman, R. (2012). How we got here: The emergence of the Common Core State Standards. State Education Standard, 12(2), 4-8.

Sawchuk, S. (2012). Many teachers not ready for the common core. Education Digest, 78(2), 16-22.

Scholastic \& Bill and Melinda Gates Foundation. (2013). Primary sources: America's teachers on teaching in an era of change. Retrieved from http://www.scholastic.com/primarysources/2013 preview/Primary SourcesCCSS.pdf.

Schraw, G. (2006). Knowledge: Structures and processes. In P. Alexander \& P. Winne (Eds.), Handbook of educational psychology (pp. 245-263). Mahwah, NJ: Erlbaum.

Shanahan, T. (2013). The Common Core ate my baby. Educational Leadership, 70(4), 10-16.

Sleeter, C. (2007). Democracy, equity, and accountability. In C. Sleeter (Ed.), Facing accountability in education: Democracy \& equity at risk (pp. 1-12). New York, NY: Teachers College Press.

Sleeter, C., \& Stillman, J. (2007). Navigating accountability pressures. In C. Sleeter (Ed.), Facing accountability in education: Democracy \& equity at risk (pp. 13-29). New York, NY: Teachers College Press.

Smith, T. W. \& Strahan, D. (2004). Toward a prototype of expertise in teaching: A descriptive case study, Journal of Teacher Education, 55(4), 357-371.

Turner, J. C. (2006). Measuring self-regulation: A focus on activity. Educational Psychological Review, $18,293-296$.

Valencia, S. W., \& Wixson, K. K. (2013). Suggestions and cautions for implementing the reading standards. Reading Teacher, 67(3), 181-185. doi: 10.1002/TRTR.1207

Vygotsky, L. (1978). Mind in society. London: Harvard University Press.

Walker, T. (2013, September). NEA poll: Majority of educators support the Common Core State Standards. NEA Today. Retrieved from http://neatoday.org/2013/09 /12/nea-poll-majority-of-educators-supportthe-common-core-state-standards/.

Wixson, K. K. (2013). In conclusion: On implementing the Common Core Standards successfully in grades $3-$ 5. In L. M. Morrow, K. K. Wixson, \& T. Shanahan (Eds.) Teaching with the Common Core Standards for English Language Arts, Grades 3-5 (pp. 187-200). New York, NY: Guilford Press.

Zimmerman, B. J. (1998). Academic studying and the development of personal skill: A self-regulatory perspective. Educational Psychologist, 33, 73-86. 